\title{
The Enlightenment of the Educational Thought of the Communist Manifesto to Postgraduate Education*
}

\author{
Gaohe Wang \\ School of Marxism \\ Jinan University \\ Guangzhou, China 510632
}

\begin{abstract}
The Communist Manifesto scientifically discusses the nature and role of education, reveals the objective laws of educational phenomena attached to social material living conditions and social relations, and discusses the education of people-oriented, human comprehensive development and education and production methods. The theory has important implications on graduate education in China.
\end{abstract}

Keywords-Communist Manifesto; educational thought; postgraduate education

\section{INTRODUCTION}

The Communist Manifesto is the greatest programmatic document of scientific socialism and a systematic and rational understanding to Marxism, and it is obviously scientific and revolutionary. Marx and Engels outlined all the scientific understanding and political experience gained during the period from 1843 to 1848 in the Communist Manifesto. Both their own experience and the experience of the working class, briefly discussed their theoretical basis, namely dialectical materialism and historical materialism, political economy, class struggle and society. In this famous work, Marx and Engels not only comprehensively and systematically and profoundly expounded the basic theories of scientific socialism, but also expounded the problem of proletarian education with the basic viewpoints of dialectical materialism and historical materialism, including rich education thoughts. So it has an important guiding role in China's higher education, especially postgraduate education.

\section{THE ESSENCE OF EDUCATION IN THE COMMUNIST MANIFESTO}

Marx and Engels believe that as a complex social phenomenon, education is produced by the emergence of society and is determined by the material living conditions and social relations. The purpose of education is to be bound by certain production relations and ideology based on this production relationship. When society develops into a class society, education also has class nature and represents the

*[Fund Project] Jinan University's Ideological and Political Project of the University of Jinan, "Xi Jinping's Ideological and Political Work Theory in Colleges and Universities, Organic Integration of University Teachers' Career Development" Jinan University's Teaching Reform Project "Xi Jinping's New Era of Socialism with Chinese Characteristics and University Teaching Research" Results. ]. interests of the ruling class. For example, the 17th century British bourgeois educator Locke proposed the educational purpose of training "gentlemen". In his view, gentlemen must be good at handling their own affairs and maintaining Britain's position in the world. He also believes that once a gentleman is educated and on the right track, other people will naturally be on the right track. The gentleman education that Locke said reflects the demand for talent cultivation in the political economy of the British aristocratic bourgeoisie.

When Marx and Engels analyzed the bourgeoisie in the Communist Manifesto, they pointed out: "The bourgeoisie erases the sacred and professional aura of all respected and awe-inspiring. It turns doctors, lawyers, priests, poets and scholars into hired laborers. The bourgeoisie has torn off the veil of warmth and enthusiasm in the family relationship, turning this relationship into a purely money relationship." Under this naked money relationship, education means to train" the vast majority of people to machines and the bourgeoisie is afraid of losing this education.

In the book The State of the Working Class in England, Engels pointed out sharply that the education of the British working class is extremely poor. The ruling class controls all the source of knowledge. What they instill in the workers is only religious fanaticism and prejudice, not the education of intelligence, spirit and morality.

In the capitalist world, workers can never get true education In order to satisfy their own desire to pursue money, capitalists as ruling classes only regard workers as tools and do not regard workers as human beings. The bourgeoisie is afraid to educate the workers. If the workers grasp this knowledge and improve their ideological consciousness, they will stand up and resist the ruling class. The purpose of capitalist education is nothing more than to separate mental and physical labor, to restrain workers' awareness, to train workers as tools, and to maintain the bourgeoisie's dominant position.

In the communist society, the proletariat is the ruling class, and the educational purpose to be realized must be the educational purpose of the proletariat. In the Communist Manifesto, "in a communist society, the free development of everyone is the condition for the free development of all people" can be said to be the educational purpose of communism. 


\section{THE ENLIGHTENMENT OF THE EDUCATIONAL THOUGHT IN THE COMMUNIST MANIFESTO TO CONTEMPORARY POSTGRADUATE EDUCATION}

\section{A. People-oriented, Life-oriented}

According to Marx's exposition of human nature, the characteristics and social characteristics of human beings determine that the essence of education should include the two aspects of satisfying the needs of human and physical development and satisfying the social reality. The former belongs to the ontological value of education, while the latter reflects the instrumental value of education. The essence of education reflects the organic combination of instrumental value and ontological value.

On the one hand, human development requires the development of society as a premise and foundation. Each generation of new individuals will encounter constraints on productivity and production relations, but it cannot be said that he is only passively adapted to the ready-made environment. In social life, people will continue to generate new needs, and consciously transform nature and society, create new living conditions, and meet their own needs. As the main body of social life, as the bearer of productivity and scientific culture, man's pursuit of his own personality development and the realization of this pursuit play an important role in social progress. Marx fully affirmed the role of human development in social development. In the German Ideology co-authored by Marx and Engels, it points out that people's production relations are compatible with the development of productive forces in the same period at every stage of historical development, so their history is also developing, it is the history of productivity that the new generation has endured and is thus also the history of the development of the individual's own strength. Education also promotes and continues the development of human society by socializing individuals. Therefore, the liberation, development and improvement of people are not only the starting point of education, but also the highest purpose of education. Therefore, education should be people-oriented.

On the other hand, the ultimate purpose of education is to promote the continuous renewal and development of human society. People receive education to improve their own value in order to better adapt to the needs of social development in order to achieve their social value. Therefore, education must serve the society, and the two are dialectical and unified.

Therefore, in socialist society, education only aims to promote the development of human personality, affirming the subjective position of human beings, enhancing the freedom of people in transforming nature and transforming society, comprehensively improving people's quality and improving people's intrinsic value to continuously push the society forward.

Maslow's hierarchy needs theory fully embodies humanistic thinking. He believes that human needs are divided into five levels: physical needs, security needs, emotional needs, respectful needs, and self-fulfilling needs. These five needs are people's different levels of motivation, constantly urging people to meet these needs, only to achieve these five needs, and talent can be a real person.

In school, the object of education is students, and the education of the school is to promote the physical and mental development of students. Putting people-oriented thinking into school education is student-oriented. Students have a variety of needs, and these needs form a variety of learning motivations for students. I believe that teachers should respect the needs of students, although some needs are relatively on a low-level. For example, if a student studies hard to achieve good results purely for emotional needs and wants to be welcomed by classmates, then the teacher should respect his motives and can guide but not force him to promote his motivation to the height of society and self-realization.

In postgraduate education, the mentor plays a big role. In the Confucianism of China, we have been emphasizing the importance of respecting teachers. Respecting the mentor is necessary. However, in the people-oriented era, more and more scholars have proposed to pay attention to the interests of students in teaching, emphasizing "student-oriented".

First of all, the mentor should understand his students, observe his motivation to learn, and teach students in accordance with their aptitude. Some postgraduate students study in order to gain more knowledge and improve their academic research ability; while some postgraduate students only want a diploma to seek a good job. Although the purpose is different, it is essentially to achieve self-value in society. The mentor cannot arbitrarily judge student's motivation. I believe that any motivation can be recognized as long as it helps to learn without hindering the interests of society. The mentor can cultivate students according to their different characteristics and motivations, so that the students can do their best to enable them to learn the knowledge and skills that are useful for their future development.

Secondly, the mentor should consider the interests of the students in education and teaching, consider from the perspective of the students, and think more about them. For example, some mentors have many jobs and seek for fame and money, and pay no attention to academy. The mentor does not have the energy to cultivate talents, and even requires students to match the leisure time of the mentor. This phenomenon emphasizing respecting the interests of mentors arouses the dissatisfaction of students. Students are eager to get the academic guidance of the mentor, not the control of some academic authority. Students have the right to express their thoughts and wishes and to express their opinions on the mistakes of the mentor. In addition, the learning way of postgraduate students is mainly self-study. The mentor should give students the right to learn independently according to their interests, instead of requiring students to take courses in the mandatory command-based management. The mentor should cultivate his moral integrity, pay attention to the unity of the teacher's morality and ability, pay close attention to the students' interests, and establish a good teacher-student relationship with the students, so as to help the students learn. 


\section{B. Realizing the Overall Development of People to Improve Students' Various Abilities}

The Communist Manifesto pointed out that the education of the working class by the bourgeoisie is an "alienation education". "The kind of education that the bourgeoisie fears to lose, for most people, trains people into machines." Capital is independent and personal, but the active individual has no independence and personality. Workers are bound by the old system of division of labor, sacrificing their own personality, and are in a state of development that is not free. In their view, the all-round development of a person is the full and complete development of the individual's physical strength and intelligence, so that the two are closely integrated.

The all-round development of people is inseparable from education, and it is inseparable from the all-round development education. In order to cultivate people with all-round development, for education in capitalist society, Marx and Engels proposed a comprehensive range of educational content including intellectual education, physical education, and comprehensive technical education. Through these aspects of education, people's physical strength and intelligence can be harmoniously developed, and the individual become a newcomer with comprehensive physical and mental health, combination of body and brain, and all kinds of skills.

In 1957, after the socialist transformation of the ownership of production materials was basically completed, Mao Zedong proposed at the Supreme State Council: "Our educational policy should enable educators to develop in moral education, intellectual education, and sports, and become cultural workers with socialist ideology. At this stage, China vigorously promotes the implementation of quality education, and demands the "ideal, intellectual, physical, aesthetic, and labor development" of students with the "all-round development" education.

In the university, how to achieve the all-round development of postgraduate students? First of all, in the aspect of moral education, we must pay attention to improving the moral cultivation and academic research spirit of postgraduate students. Students should have ideals, ambitions, develop correct values, and carefully plan their careers. The postgraduate students are generally around 25 years old. They are active and energetic. They should dare to ask questions about scientific issues, boldly innovate and explore in depth. In academic research, they must abide by academic norms and respect the labor results of others, without plagiarism or misappropriation. They should cultivate their own independent personality, enhance the subjective consciousness, and the pioneering spirit. Secondly, in terms of intellectual education, the main task of postgraduate students is academic research. Therefore, they must constantly think about improving their own thinking ability while studying. At the same time, they should read a large number of domestic and foreign literatures extensively and systematically, and learn from domestic and foreign advanced achievements for academics and lay a solid foundation for innovation. In addition, the mentor should provide an open academic atmosphere for postgraduate students, and create more academic exchange opportunities for the majority of postgraduate students. On the one hand, he can timely understand and grasp the progress of postgraduate students' research, on the other hand, he can make postgraduate students learn how to think about problems and solve problems effectively, broaden the knowledge, and spark new ideas in the report and discussion. Thirdly, in terms of aesthetic education and labor education, emphasis is placed on aesthetic ability and practical ability. In research, empirical methods are often used, which requires students to have strong hands-on skills. The mentor should develop the practical ability of postgraduate students, so that students should learn to apply the theory to practice for testing. In addition, the mentor should encourage students to participate in the school or social practice activities on the basis of ensuring the coursework, and comprehensively train students' various abilities, such as social ability, communication ability and leadership ability, which has a great help on life development for postgraduate students.

\section{Combining Education with Production Labor to Cultivate Students' Practical Ability}

The combination of education and productive activity is one of the important contents of the Communist Manifesto's educational thoughts, and is regarded as the only way to cultivate people with all-round development. Personal development is achieved in the community, and only in the community can individuals gain access to fully develop their talents. No one can develop without the society and community and must be constrained by various factors, so we should absorb the achievements of the predecessors, and develop in a certain social relationship and in the process of dealing with others. Therefore, people have social nature and subjective initiative, and only in practice can they reflect human values. In the education of postgraduate students, students are also often involved in social or collective practice.

On campus, the opportunities to combine theory with practice are few and far between. The practical exercise of postgraduate students generally refers to participating in the subject exploration. The subject inquiry refers to the cultivation of innovative practice ability through the research of the subject based on the background of professional knowledge. The method widely adopted in many colleges and universities is independent research, that is, postgraduate students independently complete course papers or scientific research topics through literature review and experimental inquiry. However, I believe that collaborative research is more conducive to student development. By participating in the mentoring project or working with other postgraduate students to complete the project, postgraduate students from different disciplines will work together to make up for each other's deficiencies and help to form a spirit of solidarity and cooperation.

In addition to participating in research projects, postgraduate students can use their spare time to enter society and participate in practice. For example, they can go into a professional-related institution and apply what they have learned to a specific job. In addition, in the applied disciplines, they can also combine production, study and research, and combine the school-based school education with the production and research practices directly based on practical experience to cultivate their application ability. 


\section{CONCLUSION}

In summary, Marx and Engels proposed in the Communist Manifesto that the educational nature of scientific socialism is different from the educational nature of capitalism. In the socialist society, the essence of education is to achieve the free development of all people. The educational thought of the Communist Manifesto plays a great guiding role in the current postgraduate education. The mentor should be student-oriented, respect the needs and interests of the students, teach students in accordance with their aptitude, make the postgraduate students develop in an all-round way, strengthen the education of moral literacy, and improve the students' knowledge, innovation, scientific research ability, social communication ability, etc. The good atmosphere and the conditions for participating in the exploration of the subject enable the students to apply the knowledge they have learned to practice.

\section{REFERENCES}

[1] Zhang Shenxi : Humanism and Modern Implication in Communist Manifesto [J], Journal of Zhengzhou University (Philosophy and Social Sciences Edition), 2009(3) (in Chinese)

[2] Luo Jun: An Analysis of Educational Thoughts in the Communist Manifesto, [J], Science and Education Forum, 2008 (3). (in Chinese)

[3] Liu Xuesheng: A Brief Comment on the "People-Oriented" Thought in the Communist Manifesto, $[\mathrm{J}]$, Journal of Social Sciences of Shanxi Higher Education, 2009(5) (in Chinese)

[4] Zheng Wei: Analysis of Modern Educational Thoughts in the Communist Manifesto, [J], Success (Education), 2009(5) (in Chinese)

[5] Wang Lijun: An Analysis of Marxist Educational Thought in the Communist Manifesto, [J], Journal of Adult Education College of Hubei University, 2006(6) (in Chinese) 